\title{
Mycoplasma hominis
}

National Cancer Institute

\section{Source}

National Cancer Institute. Mycoplasma hominis. NCI Thesaurus. Code C86597.

A species of anaerobic, Gram-negative, pseudo-cocci shaped bacteria assigned to the phylum Firmicutes. This species is nonmotile, metabolizes arg inine with the subsequent release of ammonia into the broth medium, resistant to penicillins and cephalosporins, while tetracycline (adults only) and erythromycin are effective chemotherapeutic agents. M. hominis is commensal in the urogenital flora of adults, but is an opportunistic pathogen implicated in female genital infections and may also cause infections in newborns, especially in those that are immunosuppressed. 